\title{
Logistics Management Building Mechanism in E-Commerce
}

\author{
Wanwan Zhang,Shiying Fang,Bin Huang \\ School of Media Studies\&Humanities,Zhejiang University City College,Hangzhou, 310015, China \\ E-mail: binshuirita@sina.cn
}

\begin{abstract}
E-commerce is a product of the information-based society. Its ripad development has also stimulated the logistics industry which it depends on . The importance of logistics in e-commerce has become apparent .If we do not have an efficient, reasonable, smooth logistics system the advantage of e-commerce would be difficult to abtain . This difficulty would be made evident in the complexity of the modern logistics industry and China's development status with characteristics of national conditions. At present China's e-commerce logistics industry exists with many disadvantages and risks. We must get to the bottom of its management deficiencies and take actions to improve it and then build an E-commerce logistics management system with Chinese characteristics. thease improvements must includde improved logistics management .
\end{abstract}

\section{Keywords-e-commerce;logistics;china;management;risk}

*Wanwan Zhang is the first author;Shiying Fang is the correspondence auther;Bin Huang is the instructor;

\section{INSTRUCTION}

With the development and popularization of the Internet,The rapid rise of e-commerce has greatly promoted China's e-commerce..According to the China Electronic Commerce Research Center monitoring data shows that as of June 2012, the domestic e-commerce service enterprises reached 38,780 , an increase of $8 \%$.B2B e-commerce service enterprises amounted to 10,950, the the domestic B2C, C2C and other electricity providers mode number of enterprises reached 24,620, compared with last year, an increase of $20.1 \%$. (please refer to Figure 1)

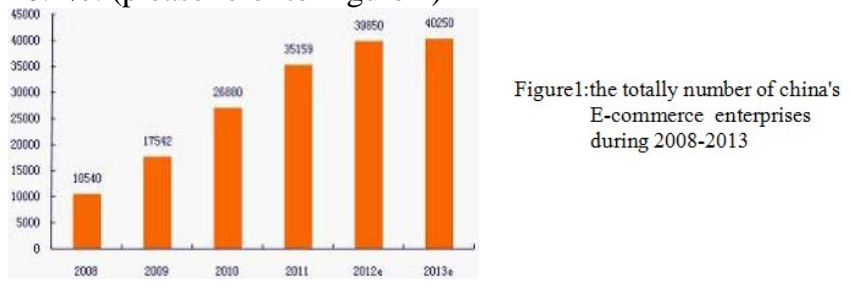

Source :China Electrionic Commerce Research Center
Figure 1. The rapid rise the China Electronic Commerce Research Center monitoring data shows that as of June 2012

The development of e-commerce also has promoted the rapid development of the courier industry. Chinese ecommerce Research Center (100ec.cn) of monitoring data shows that in the first half of 2012, the national-scale express companies' volume of business totally reaches 2.4 billion, this is an increase of $50 \%$ compared to the same period last year and vulume of business for the express delivery industry to $15 \%$ annaul .the counpound annual growth rate upgrade to chieve 24 consecutive months of growth rate of over $50 \%$ As of June 2012, the size of the domestic online shopping courier company's revenue reached 46.83 billion yuan, a year-on-year growth of 39.8\%. (please refer to Figure 2).

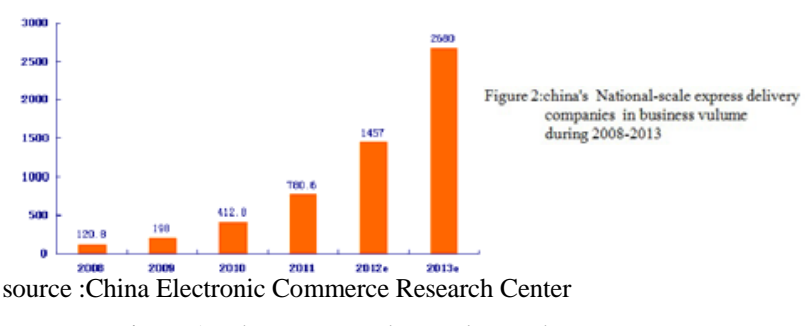

Figure 1. the counpound annual growth rate

Since the 1990s, the logistics became one of the hot spots of the whole world.The main reason is the intense changes of the business environment and information technology applied to business operations, resulting in the change of the business model. These changes give new connotation of Logistics and Logistics Management.The logistics for e-commerce has become increasingly obvious, an efficient logistics system can improve the effectiveness and efficiency of e-commerce, to coordinate their goals, and to expand its range of e-commerce-based supply chain integration. These improvements will enhance their competitiveness.It will also be understood September 8, 2012,that Alibaba had invested \$ 100 million in logistics, This is an unprecedented large investment.

Even with business flow, capital flow, information flow, logistics , and the first three follow closely the rapid development but logistics become a bottleneck in the development of electronic commerce. Modern logistics relative to the traditional mode of transport, it is more complex, it includes packaging, handling, distribution processing, distribution, and many other aspects.modern transport changes from single traditional transport to sea land 
and air transportation. Also makes modern logistics, risk management is not limited to traditional transport and warehousing, it needs more entrepreneurs from a comprehensive point of analysis, control, in order to reduce logistics risks.

China Electronic Commerce Research analyst daiqing Mo said. "Rapid development of online shopping, no doubt to the logistics challenges. Logistics mode from city to city and then stores this mode, direct refinement to the user from the merchant, which is an end-to-end service capabilities. Mistake, and material loss rough, big, ultimate service and satisfaction is low, the high cost of logistics problems have constrained the development of e-commerce. "

The analysis of the e-commerce logistics.In our country, it started late, which reveals the low level of logistics. China has the unique in the economic, market, politic , culture system. In today's age of electronic commerce, modern logistics for e-commerce activities still have many problems . Its logistics risks can not be discounted. to some extent, because it may restrict the development of e-commerce. For this reason, it is imperative to build e-commerce logistics management system for the development of e-commerce.

\section{CHINA'S E-COMMERCE LOGISTICS CAUSED LOGISTICS RISKS DUE TO MISMANAGEMENT}

A. The risk between logistics provider and customers:

- Logistics and security. cargo suffer a loss in transportation, handling, storage and inventory activities due to displacement or due to improper storage conditions ;

- Logistics timeliness. under requirements of the principle of JIT, logistics enterprises delay distribution often leads to customer claims. In practice, however, most of the customer claims based on the logistics service agreement. In other words, the third party logistics enterprises should take responsibility for liquidated damages. The report released on January 1, 2012, by the China Electronic Commerce Research Center, revealed in the first half of 2011 a fourth of the volume of complaints reported were in "China's e-commerce complaints with the rights of public service platform" one-half;

- Logistics accuracy. indistinct handmade bill, information systems error, human's careless make that the goods are sent to the wrong places or wrong persons. In contract laws, the parties filed lawsuits in liability or breach of contract responsibility v. option;

- Logistics Service. failed to oversee the logistics of real-time dynamic information system failed to identify all occurrences and the potential logistics operation obstacles logistics service measure emphasized in modern logistics can not be guaranteed.

\section{B.The risk between logistics providers and subcontractors}

- Transitive risk. third-party logistics enterprises can't pass to all the risks effectively by subcontracting agreement. Subcontractors' liability amount is far less than the amount of liability signed by the customer, in the event of an accident, third-party logistics required to bear the difference, and the public enterprise sector in China is generally provided lower liability limits, when the third-party logistics enterprises choose them as subcontractors, they will be faced with the risk of not effectively pass;

- Fraud risk experiencing bad qualified subcontractors will happen because of the risk of missing inventory, reslting in fraud caused the cargo .

C.Logistics provides liability risks that may arise between the parties and the general public ---- infringement risk

- The risk of environmental pollution: environmental pollution, mainly in the activities of third-party logistics, traffic congestion, motor vehicle exhaust emissions, noise, etc.. Under the Environmental Protection Act, the polluter should take legal responsibility to pubilic.

- Traffic Accident Risk: transport drivers traffic accident occurs in the process of transportation of goods, belonging to the behavior of the performance of their duties, their civil liability should be borne by its logistics enterprises belongs.

- The risk of leakage of dangerous goods: Dangerous Goods Logistics has leakage risk, it's ready to give security of life and property of the public threat, this worthy enterprise engaged in dangerous goods logistics should be vigilant about it.

\section{CHINESE E-COMMERCE LOGISTICS MANAGEMENT} IS INSUFFICIENT

\section{A. Question of perception, heavy business flow, light logistics.}

People are lack of modern logistics concept, most of the enterprises of the lack of knowledge of the role of modern logistics in the transport industry level, to promote economic development and increase economic benefits will greatly affect the outcome. The result of not recognizing national economy or business management not attach importance to logistics, lack of planning, will cause a serious shortage of investment; the existing storage and transportation must be seen as the entire contents of the logistics, regard electronic commerce as a simple computer streaming sports. Understanding the real e-commerce implementation process should include the use value of goods, which is not yet recognized that the implementation of e-commerce is a complex system engineering.

\section{B. Imperfect logistics infrastructure.}

Logistics infrastructure including roads, railways, ports, airports, and network communication foundation. Must be determined ,the utilization rate of old logistic facilities in 
Chinaare not high. The transport equipment, handling machinery, packaging tools, maintenance tools,reveal obsolete equipment, the infrastructure can not be mechanized, automated, and they are inefficiency, and communications equipment and lines, fax machine, computer and the lack of network equipment and IT hardware facilities can't keep up with the requirements of the e-commerce logistics. In addition, due to the logistics management can not keep upwith the demands, resulting in inefficient use and to make originally stale logistics facilities can not meet the needs of electronic commerce.

\section{The backward of Logistics management, technology} slow construction of logistics information.

Due to the lack of advanced science and technology, the logistics management cannot maintain the real-time dynamic information system is not timely manner .The information is not synchronized, asymmetry. Managers should be provided forecast, regarding the inaccurate order quantity, and price fluctuations, which are in cargo supply chain,and then it will cause harm the huge bullwhip effect bullwhip effect "

\section{The scarcity of talent.}

In China's e-commerce logistics, highlights several talents defects: risk awareness (For business managers, the biggest risk is not know the existence of the risk), the management is not professional, management is not strong sense of responsibility integrity is not enough, no sense of service. China lacks professsional senior management persons who has a certain level of logistics knowledge and practical experience. Education of logistics in China is still relatively backward, lack occupational logistics talents, that they can not meet the needs of the rapid development of ecommerce logistics.

\section{E. Traditional storage, transportation system and the} means hinder the development of modern logistics.

Not being fully aware of the logistics of electronic, single storage and transportation as well as storage and transportation of backward technology stifle the development of modern logistics logistics

\section{F. The slow development of third-party logistics services.}

The service functions is single, currently the third Logistics party gains $85 \%$ from basic services, such as transportation management and warehouse management, like cannibalization of goods, re-packaging, test and repair, and other value-added services, financial services and logistics information services and support logistics only $15 \%$; smaller market share of small-scale enterprises, and only $18 \%$ in the production of raw materials, logistics, commercial enterprise logistics accounted for only 5.9\%; certain extent limited diversification of logistics services, affecting the quality of logistics services; low level of information technology, there is no effective mechanism of information with partners to establish an information platform, or to obtain timely and accurate information.

\section{CHINA'S E-COMMERCE LOGISTICS MANAGEMENT BUILT}

Logistics Management System is a large and complex systems engineering. Not rely solely on the strength of a business will be able to complete. Therefore, we must stand in a certain height, to look at this issue from a macro point of a comprehensive analysis.

\section{A. From the enterprise itself:}

1) Improving awareness of e-commerce logistics. The increased emphasis on the importance of logistics, recognizing its economic benefits, elevating the logistics to the status of an enterprise competitive strategy, and recognize that e-commerce is not just a computer business but it also in cludes flow activies and the use of the vule of goods in complex engineering. In order to appreciate advanced ideas and theories, there should be an awareness of the responsibility of investments, and foreign modern ecommerce logistics theory.

2) Appropriate e-commerce logistics system design. Provides a clear about variety of goods, items subject to a very special delivery requirements, collect the data of characteristics of goods, traffic, environmental conditions, economic data, commodity handling equipment. Choose The best match by adjusting the controllable factors, observing trend of system performance, so as to select the controllable factors, to achieve the best results of the system. Such as inventory management, according to the forecast, at all levels in the supply chain, the impact of the inventory of the different forms of the implementation of the different production, distribution, inventory control strategy, which greatly saves cost, but also demonstrates the enterprises' quality customer service. Such as Wal-Mart establishes between CPFR (Colaborative planning forecasting and replenishment) systems with supplier to chieve to plan forecast, replenish together .

3) To strengthen the management of the supply chain. The essence of supply chain management is efficient and effective manner to meet customer demand. Supply chain determines Chen product availability, speed and cost of the product to reach the market. Efficient logistics and supply chain management can significantly reduce costs, affect the final price of goods and services, and affect customer value. In China, Galanz becomes the production of giant microwave industry through price competition.

4) Improvement of logistics equipment and technology.

- Equipment and facilities: transport loading and unloading equipment are complete; warehouse has corresponding inventory equipment, such as shelves, metering devices, management control system. with special equipment to control temperature, humidity, ventilation characteristics of goods; higher degree of automation of processing equipment; packaging 
mechanization should be compatible with modern mass production; efficient and reliable communication equipment hardware and software; reasonable allocation of nodes in the logistics.

- Logistics technology: transport, handling, packaging, warehousing, in-kind real-time tracking technology to master, but also be familiar with modern computer technology, such as GIS, GPS, EDI, BAR CODE, etc.

- Information Technology: Information is the important foundation of enterprise logistics management and business development. Companies must be willing to IT investment, enterprises build information systems, are supported by quality information, can reduce the uncertainty in the market, thereby to reduce the bullwhip effectin the demand process .

\section{B. From the national environment:}

\section{1) Talents.}

- Set up a dedicated e-commerce and logistics research institutions or research projects in the undergraduate colleges and universities or tertiary institutions .

- $\quad$ at the same time to take a variety of forms, combine the schooltraining and on-the-job training, combine the long-term training and short-term training .

- based on a coordinated, scientific planning, to carry out the technical, economic and professional management.we should learn from foreign advanced logistics concepts and logistics technology actively. strengthen international exchanges and cooperation, regularly organize international logistics seminar, promote the development of the logistics industry in China's e-commerce environment.

2) Vigorously develop the third-party logistics.

Third-party logistics enables companies to focus on the core business of the limited human, material and financial resources to achieve optimal allocation of resources and the formation of large-scale production. At the same time, if we provide a multi-functional service, strive for value-added logistics services to improve the quality of logistics services, and to improve the level of information technology. will be given the logistics also brought third-party profit.

3) Strengthen the government's macro-guidance and policy control. emphasis

- Strengthen social credit system construction, focuse on the values of integrity guide, organic integration of social resources, and guide corporate integrity and self-discipline, and to establish a fair and honest environment;

- $\quad$ put the development of society electronic logistics system arrangement in the agenda;
- about tpl supporting : the government encourage social of specialized third-party logistics development actively, to third-party logistics if it's necessary , give some financial support, including direct government investment, government preferential loans;

- $\quad$ encourage industrial and commercial enterprises and logistics service company formed a logistics alliance to build a high-quality, high-efficiency, low-cost supply chain;

- Reform logistics institutional barriers, establish the necessary mechanism for the coordination of government departments, the government help to some associations to build logistics committee to formulate national modern logistics development planning .

4) Legal aspects of perfection.

Awarded the logistics and regulations; perfect China's logistics Law loopholes in the law, so that it will more clearly define; judicial authorities strengthen supervision and law enforcement, against e-commerce merchants who lose the trust of the fight, dishonest behavior in e-commerce activities should be held liable in accordance with the law.

5) The media and public education.

E-commerce and e-commerce logistics should be together publicity, popularize the people about the importance of logistics; the use television, radio, newspapers, mainstream media, to increase social integrity mechanisms publicity, to create a good public opinion environment. Medias publicity of corporate social responsibility, environmental protection concept will let the logistics enterprises to strengthen the management process of logistics transportation, equipment consciously .

E-commerce as a new way of Being Digital, represent the future of the trade, consumption and services, it needs the overall ecological environment, there needs a break from the traditional pattern of the original industry, An intergration of a four-stream system for the social ecommerce system of logistics and distribution system, will produce an optimized logistics management system, establish ing the real business of logisitics is part icularly important , and its significance will be far-reaching .

\section{REFERENCES}

[1] X.J.Wei, J.Y.Yan, Y.Wang, Z.H.Yuan "E-commerce Logistics"Dec 2008 PP 27--56

[2] X.F.Wang, F.Zhang, B.G.Shan, "International Logistics Risk and Insurance"Mar 2010 PP165--188

[3] S.S.Gu , X.H.Bi ,"Commerce and Modern Logistics Management"Spet 2011 PP46--112

[4] L.Jing "The logistics risk control and Prevention"Spet 2010 PP10--76

[5] H.Zhou, X.Q.Luo "Logistics and e-commerce".No 2011 PP 89--135 